\title{
RETHINKING THE PARLIAMENTARY SYSTEM: CONTRIBUTIONS FROM THE AUSTRALIAN DEBATE
}

\author{
CHERYL SAUNDERS*
}

The author considers whether the parliamentary system is an effective institution by examining its capacity to handle its five traditional functions. Those functions are: maintaining the government, passing laws, controlling government expenses, monitoring the government of the day, and setting long range policies. She concludes that parliaments are incapable of performing these functions on a consistent basis. This incapacity stems from a variety of factors including party discipline, the passive nature of members of parliament, and the fact that there is no separation of powers in the parliamentary system. To remedy these shortcomings she calls for changes which are aimed at giving parliament greater independence from the executive branch. She notes that these changes may require a radical departure from traditional political theory in countries that have adopted parliamentary systems. However, the parliamentary system has not changed in over 300 years. If it is to serve its citizens effectively in the future, perhaps a radical departure from tradition is required.
L'auteur examine si le systeme parlementaire est une institution efficace en évaluant sa capacité $d$ assumer ses cinq fonctions traditionnelles: maintenir le gouvernement, adopter les lois, contrôler les dépenses du gouvernement, surveiller le gouvernement au pouvoir et établir les politiques a longue échéance. Elle conclut que les parlements sont incapables de remplir ces fonctions de façon constante. Cette incapacité est attribuable d divers facteurs, parmi lesquels la discipline de parti, la nature passive des membres du parlement et le fait que la séparation des pouvoirs n' existe pas dans le système parlementaire. Pour remédier à ces faiblesses, elle propose des changements qui visent a donner une plus grande indépendance au parlement en matière de pouvoir exécutif. Elle note que ces changements pourraient signifier un tournant radical dans la théorie politique traditionnelle des pays qui ont adopté le système parlementaire. Néanmoins, il n'a pas changé en plus de trois cents ans et, s'il prétend servir ses citoyens efficacement dans l'avenir, peut-être que ce tournant radical lui serait salutaire.

\section{TABLE OF CONTENTS}

I. INTRODUCTION $\ldots \ldots \ldots \ldots \ldots \ldots \ldots \ldots \ldots \ldots \ldots \ldots \ldots \ldots \ldots$

II. ROLE OF THE LEGISLATURE $\ldots \ldots \ldots \ldots \ldots \ldots \ldots \ldots \ldots \ldots$

III. FUNCTIONS OF PARLIAMENT $\ldots \ldots \ldots \ldots \ldots \ldots \ldots \ldots \ldots, 341$

A. FOUNDATION FOR GOVERNMENT $\ldots \ldots \ldots \ldots \ldots \ldots, 341$

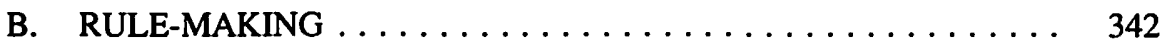

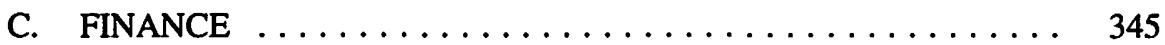

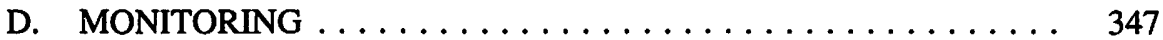

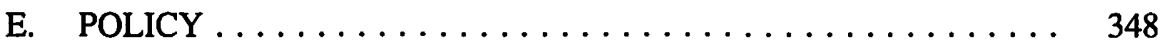

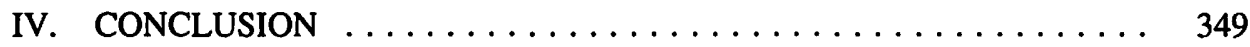

\section{INTRODUCTION}

The tercentenary of the glorious revolution of 1689 is an appropriately symbolic occasion for reflection on the operation of the parliamentary system. Whatever other

Professor of Law, University of Melbourne. This paper was originally delivered at the University of Victoria, British Columbia as a Lansdowne Lecture on November 15, 1989. 
interpretation may be given to the events of that year, they marked an important stage in the achievement of parliamentary supremacy over the Crown and in the evolution of the concept of parliamentary sovereignty. As political parties developed and became tightly organized, parliamentary sovereignty in turn became the vehicle for the concentration of power in executive government - the hallmark of systems deriving from the British model. A parliamentary system has significant advantages in terms of speedy implementation of the policies and programs of an elected government. Potential disadvantages lie in the absence of institutional checks and balances, unless the system is modified to provide them. Paradoxically, this model also raises questions about the functions which its central feature, the legislature, is now required or expected to perform.

I do not intend to give the impression that there is a widespread or cohesive debate in Australia on the role and operation of parliament, because there is not. Even the major constitutional review which culminated in the bicentennial year of 1988 barely touched on the issue, beyond noting an argument that parliament was in decline. ${ }^{1}$ The Constitutional Commission's terms of reference required it to work within the parameters of parliamentary government. ${ }^{2}$ While many of its recommendations would have affected particular parliaments, none went squarely to the fundamental question of their role. Nevertheless, the phenomenon of executive domination of parliament is as familiar in Australia as elsewhere. As in Canada, moreover, the natural tendencies of the system are aggravated by a network of intergovernmental arrangements which further inhibit independent action by individual parliaments, add another layer of complexity to the system, and provide additional justification for the withholding of information on the grounds of confidentiality.

The principal stimulus for the choice of this topic at this time is a series of disparate issues that are current in Australia. Each of them reinforces the need to determine the functions which a parliament is required to perform and to ensure that it is able to perform them. Most recent, and with the highest profile, was the unusually clear and unqualified affirmation of the need for an effective legislature in a healthy system of government by Mr. Fitzgerald, Q.C., in the report of his inquiry into allegations of corruption in Queensland. In the face of evidence of a breakdown of probity and accountability at all levels of the public sector in Queensland, the Fitzgerald Report argued that it was "much less likely that a pattern of misconduct will occur in the Government's public administration if the political processes of public debate and opposition are allowed to operate, and the objectives of the parliamentary system are honestly pursued. ${ }^{13}$ Shortly beforehand, on the other side of the continent, a Western Australian investigation into huge financial losses by government enterprises had similarly recommended improvement in the accountability of government to parliament as a remedy.

I. Constitutional Commission, Final Report, 1988, Vol. 1 (A.G.P.S.) at 97.

2. Ibid. at 1.

3. Report of a Commission of Inquiry Pursuant to Orders in Council (Fitzgerald Report), (Queensland Government Printer, 1989) at 123. 
A different aspect of the debate, which has concerned me more closely, has involved the relationship between the administrative review system and parliament. Critics of administrative review sometimes argue that it duplicates the functions and usurps the prerogatives of parliament. I suggest later that, on the contrary, administrative review complements the functions of a modern parliament depending, of course, on what its functions are. Similar arguments tend to be made in the debate in both Australia and New Zealand about whether individual rights should be constitutionally entrenched. They involve the familiar claims that rights are adequately protected by the parliamentary system and that a bill of rights represents an unacceptable transfer of authority to an unelected judiciary. In Australia, at least, it seems likely that these arguments will prevail for the foreseeable future, making more crucial than ever the effective operation of parliament.

\section{ROLE OF THE LEGISLATURE}

There are some notable inconsistencies in the collective views expressed about the role of a legislature in a parliamentary system. It is notorious that the institution on which so much reliance is placed, in the context of the debate on constitutional guarantees of rights, in fact is subject largely to executive direction. By definition, the Ministry controls at least the lower House of the legislature, except in the relatively rare case of a minority government. Policy is forged by the government and/or the public service. Once the point of legislation is reached, it is usually assumed that the battle is over. The theoretical sanctions of withdrawal of confidence, amendment, or rejection of government measures, in practice, are most unlikely to be used.

That bleak picture is subject to some qualifications, of course. The very existence of a parliamentary process influences the policies which a government is prepared to initiate and the attitudes it is prepared to take. The legislative stage may be more significant for particular high profile measures or where parliamentary procedures are protracted. The discipline of periodic election makes government reasonably responsive to the wishes of the electorate, however those wishes may be identified. Nevertheless, in Australia at least, the compliance of parliament is taken for granted. Its significance in the process of government tends to be overlooked to the point where it is treated with contempt. One Western Australian Minister, for example, was recently quoted as saying, "I think (Parliament is) not only personally degrading but a waste of time."

A further inconsistency attends discussion of bicameralism. Historically, upper Houses in Australian parliaments have been a major cause of constitutional crises. One of the most recent, which gave the Australian system world notoriety, was the dismissal of the Prime Minister by the Governor-General in 1975, following deferral of the appropriation and loan bills by the Senate. Inevitably, there has for a long time been a widespread view that upper Houses are anachronisms from an earlier, less democratic age which serve only

4. The Australian (5 August 1989). 
to unnecessarily duplicate the role of the lower House or to unacceptably frustrate the will of a democratically elected government. The logical conclusion is that they should be abolished and that remains the official position in some quarters.

At the same time, however, the argument that parliament is not much of a bulwark against executive government tends to be countered by reference to the role which upper Houses play. At least in relation to the Senate, this response has some force. The system of election by proportional representation which has been used since 1949 tends to produce a Senate in which minority parties are represented and in which both the government and the official opposition lack a majority. In consequence, the Senate has developed a fairly effective committee system, operating to a degree on non-party lines. Passage of legislation through the Senate, moreover, is far from a lay down misère. From the standpoint of the quality of legislation and the accountability of government the results have been beneficial. The point remains, however that these prevailing attitudes to the role of the Senate are mutually inconsistent.

In any event, I have some difficulty with the argument that the effectiveness of a legislature must depend solely on its upper House, much less on an upper House which in turn relies for its effect on chance majorities. There may well be sense in developing a theory of parliamentary government in which the upper House in a bicameral legislature plays a significant role. In that case, however, its constitution, powers, and procedures should be designed to enable its assigned functions to be performed consistently, effectively and without doing violence to constitutional principles.

The issue is far from academic in Australia. As lower Houses become recognized as relatively ineffectual, interest is growing in other checks which might be developed within the system. In the wake of the revelations about government in Queensland, the only State with a unicameral legislature, there is a tendency to consider upper Houses an obvious option. The logic is unlikely to be sufficiently compelling to cause a new upper House to be established in Queensland, but it has almost certainly created difficulty for any move to abolish those which already exist. And if upper Houses are to be a permanent feature of the constitutional system they should be put to good use.

At the heart of the confusion over the function of the legislature is the influence of the party system. It is the discipline of party organization, exercised over members of the parliamentary party, which transforms the active institution, which the traditional theory of parliamentary government assumes, into the more malleable organization that is parliament as we know it. The final paradox, however, is that a disciplined political party system appears to be essential to the effective operation of parliamentary government. In its absence, as the experience of many Pacific island countries shows, parliament is not only active but too active, making government unworkable.

It follows that whatever functions are assigned to the legislature, they must assume and build upon the continued operation of political parties. Recognition of parties as an integral component of the constitutional system might in turn, however, bring other 
changes in its wake. Amongst them might be a greater public accountability of party organizations themselves for decisions that are central to the democratic process, including admission to party membership, preselection of candidates, and codes of conduct for Members of Parliament.

The ambiguity of the role of the legislature is reflected, on a higher constitutional plane, in uncertainty about the relevance of the doctrine of separation of powers in a parliamentary system. It is clear, of course, that the type of separation of legislature and executive exemplified by the Constitution of the United States cannot apply. Nevertheless, there is Australian authority for the proposition that a three way separation of powers exists under the Commonwealth Constitution. Dignan's case in 1932, ${ }^{5}$ in which that proposition was made, involved a sweeping delegation of legislative power from parliament to the executive. Even in that context, however, the High Court failed to attach substantive consequences to the doctrine. The Court reasoned in part that a broad delegation of legislative power to the executive would not contravene the separation of powers in a parliamentary system because ultimately the parliament retained control of the executive. The tension between the theory and practice of parliamentary government is nowhere more evident than in Dignan's case.

It has become customary to dismiss Dignan as a quaint academic exercise by the Court, designed to underpin the more stringent separation of judicial power and, perhaps, as a somewhat hollow threat that the delegation of legislative power should not go too far. On reflection, however, perhaps it contains the seeds of a workable compromise on the role of the legislature in a parliamentary system. There may be potential for the doctrine of separation of powers to be adapted to reinforce the allocation of functions between the legislature and the executive. The foundations for that development already exist in the somewhat dated principles which require that certain actions of government be authorized by parliament and accept that others may be undertaken by the executive alone. A new separation of powers would require that those principles be reexamined and rationalized, by reference to all major functions performed by modern government. The doctrine would not necessarily preclude delegation, nor require the parliamentary contribution always to be made in the form of legislation. The allocation of powers and the procedures for their exercise would be determined in the light of the role which the legislature is intended to play in the constitutional system, taking into account reasonable needs for efficiency of action and speed of reaction.

For the remainder of this paper, I wish to examine five functions associated with the legislature as an institution in a parliamentary system. Three are unexceptional. The involvement of parliament in the others attracts more disagreement. In any event, I propose to show that there are difficulties associated with each function as the parliamentary system is currently practised in Australia. At the very least they suggest a loss of direction. 
For reasons of time, I do not consider the role which individual Members of Parliament play in their constituencies, whether in dealing with grievances or in providing a sounding board for electoral opinion. I acknowledge the importance of both, however; and the former again is relevant to the administrative review system. Reflection on the relationship between the role of Members of Parliament and review suggests to me that the role of individual Members of Parliament is a subject that merits treatment in its own right. My guess is that the performance of Members of Parliament in this regard varies dramatically by reference to such factors as the ability of the Member, the security of the seat and the nature of the issues in question.

\section{FUNCTIONS OF PARLIAMENT}

\section{A. FOUNDATION FOR GOVERNMENT}

A distinguishing function of the legislature in a parliamentary system, on which general agreement can be expected, is to identify the government and provide it with continuing legitimacy. Its exercise is likely to be perfunctory in the period between elections, although even then it represents an important safeguard, able to be activated in extreme circumstances.

Legitimation of the government may be a fundamental function of parliament, but presumably it is not its only function. Parliament would represent an extraordinarily elaborate and expensive device if that were so. Undue emphasis on this function, moreover, tends to encourage the disruptive and unproductive pursuit of relatively trivial issues for which parliamentary proceedings are renowned.

There are signs that even this, of all functions, has become obscured by preoccupation with the place of executive government in the constitutional system. Two examples, both of which have received some attention in Australia recently, illustrate the point. The first concerns the power of the Crown to prorogue the legislature, which by convention is exercised on ministerial advice. A government which has lost or fears to lose its majority in parliament can postpone the day of reckoning by advising prorogation at least until existing appropriations run out, which may be six months or so in the future. In the interim, much may be done in the exercise of executive power or in the implementation of existing statutes. It is at least arguable that it would be more appropriate to require parliament to be summonsed again by the Crown on petition by a majority of elected members.

The second example is drawn from events that took place in 1989, in the State of Tasmania, following an election in which neither of the two major parties received a majority and a small band of independent "green" candidates was elected to parliament. Two options were available: a new election or an agreement of some kind between one of the major parties and the greens. As the possibility hardened that the greens would support a minority Labour government and not the incumbent Liberals, there was intense 
and increasingly hysterical speculation about whether the Premier nevertheless would advise a dissolution and how the Governor would and should act in response.

In the event the outcome was an anti-climax. Parliament eventually was summonsed. The support of the greens for a Labour government was manifested on the floor of the House. The Premier advised the Governor to send for the leader of the opposition. The point is, however, that almost no one suggested that escape from the predicted impasse lay in obtaining the views of parliament at an earlier stage and/or in acknowledging that in these circumstances the views of the parliament should prevail over any inconsistent advice which the Premier might give. Meanwhile, the business of government had been carried on by a Premier who lacked the support of parliament; some controversial logging contracts allegedly were signed; and several significant appointments were made.

In both of these examples the conventional practices which have grown up around the relationship between the Ministry and the Crown have tended to protect the former against the body from which it derives its legitimacy. Discussion of these questions, moreover, has been cast in terms of the rights of an incumbent government. While it may be acknowledged, in the interests of both stability and cost, that an existing regime should not be unseated merely because of some transitory situation in the parliament, that problem should not be overstated. Where a party system has developed, parliaments are not known for their volatility. It should be possible to devise mechanisms which overlook a shift in balance in the parliament which obviously is temporary. Nor has the concern which this objection suggests been reflected in the ready acceptance of the effective power of a government to call an election at any time of its choosing, with the dominant consideration the likelihood of a favourable result. ${ }^{6}$

\section{B. RULE-MAKING}

Secondly, parliament represents the forum in which significant rules affecting the community and having the force of the state behind them are made. This function is also uncontroversial, at least on the assumption that parliament plays an essentially passive role, in the sense that it can be relied upon to pass all measures introduced by the government. Even on this assumption, however, the function is important. It requires law to be made publicly. It imposes a procedure under which Ministers must introduce proposed laws and explain their purpose. It provides some opportunity for the community to attempt to achieve alteration before enactment, even if the parliament itself is unable to do so. Laws made by the parliament are numbered and published under an established system which makes them publicly available and reasonably accessible.

It has long been accepted that pressure of parliamentary time and the extent of rule-making by modern government makes it impracticable for all rules to be made in that

6. This power has been modified in the Australian States of Victoria and South Australia, where the Constitutions provide fixed three year and maximum four year terms, reducing the period within which an election may be held to one year, in normal circumstances. 
way. Delegation of legislative power to the executive, to be exercised in the form of regulations or statutory rules is an unremarkable feature of the system. In most jurisdictions subordinate legislation is, however, subject to requirements designed to preserve to some extent the advantages of rule-making by parliament. In Australia at the Commonwealth level, for example, regulations are centrally drafted, numbered and published in a regular series. They are required to be tabled in the parliament and may be disallowed by either House. The procedures are given practical effect through a Senate Standing Committee on Regulations and Ordinances, charged with the responsibility of examining all regulations and reporting to the Senate if they appear to warrant disallowance by reference to specified criteria.

This neat framework, integrated quite well with the traditional expectations of parliamentary government, in fact covers only a fraction of the rules made by the state. A project recently initiated by the Administrative Review Council has confirmed the existence of a hierarchy of problems associated with the rule-making process. They include the complexity of legislation and, surprisingly, the apparent absence of any definitive principle to determine which rules should be included in primary, as opposed to subordinate, legislation. More relevant for present purposes, however, are three categories of other "instruments", to use a neutral term.

The first category comprises rules which unquestionably are legislative in character but which are not made in the traditional form, with its procedural safeguards. They may be called all sorts of things: by-laws, rules, determinations, directions, principles and proclamations are among the terms currently in use. Typically they are drafted in the initiating department and made by the Minister or agency head, avoiding the Executive Council. In most cases they nevertheless are subject to parliamentary tabling and disallowance, and committee scrutiny, thanks to the vigilance of the Senate Standing Committee for the Scrutiny of Bills.

While rules in this category are often required to be published in the Gazette, they are not included in any numbered series which can be systematically monitored or searched. The justification offered by some departments, that they negotiate with regular client groups in making the rules so that everyone who needs to know about them does so, is hardly satisfactory from a broader constitutional perspective. Nor, in practice, is it applicable to all rules and all clients. The Council was recently told by the representative of a welfare rights group that "the only way of finding out whether such instruments exist is to write to the administering Department and hope that they either keep a relevant index system or that someone remembers on which file the relevant instrument might be found. They are rarely included in ... Freedom of Information Act...statements." ${ }^{7}$

7. A. Anforth, Observations made to the Administrative Review Council in connection with its project on rule-making, August 1989. 
The problem, which is already large, is growing. In 1988-89 it was estimated that there were approximately twice the number of instruments in this category as in the normal statutory rules series. ${ }^{8}$

Instruments in the second category differ from those in the first because, while having many of the qualities of rules, they have not been recognized as legislative in character and the attitude of government and parliament to them is correspondingly confused. Two examples in particular stand out: the relatively new phenomenon of directions or guidelines, issued by Ministers under statutory authority, to give special status to government policy; and conditions attached to grants to the States.

It has become fashionable in recent years for statutes to empower Ministers to give binding directions on policy or priorities to statutory authorities or review tribunals whose function otherwise may be relatively unstructured. The Employment, Education and Training Act 1988, for example, which establishes a Board of the same name, authorizes the Minister to give direction or guidelines "regarding the broad social economic and budgetary priorities to be taken into account by the Board" and requires the Board to follow such directions. ${ }^{9}$ Mesmerized, as always, by arguments about the sanctity of policy, the Commonwealth Parliament so far has adopted the compromise of requiring such instruments to be tabled, without insisting on a power of disallowance. It is arguable, nevertheless, that these instruments are a substitute for statutory guidance and that procedures should be designed for them on that basis.

Conditions attached to grants to the States, by contrast, are clearly the business of parliament under an express constitutional provision, which has no Canadian counterpart, for financial assistance to be granted to States "on such terms and conditions as parliament thinks fit". Even so, it is commonplace for this power to be delegated to the executive; and rare for the product to be subject to any of the procedural requirements for delegated legislation except, occasionally and unsystematically, tabling or reporting in parliament. Despite their importance both for public accountability and the individuals affected by them these instruments, like ministerial directives, fall outside the traditionally accepted forms of delegated legislation. Instruments in this category thus present problems of access, information and participation to a greater degree than the first.

The final category comprises instruments which, under current theory, are not recognized as having legislative quality at all. In consequence they are subject to none of the procedural advantages which the rule-making function of parliament offers. Nevertheless they have many of the hallmarks of regulation through legislation, although underpinned by the economic power of the State, rather than the force of law. They include government contracts, long since accepted as executive in character but able to be used, quite systematically, for regulatory purposes. They also include the less familiar

8. O'Keeffe, "Who is watching, the regulators?" Business Council Bulletin (October 1989) 32. He estimates that there were 378 statutory rules and 779 other instruments in the course of the year.

9. Section 8. 
device of a one-line appropriation, subject to administrative arrangements to guide its expenditure, which in Australia also constitutes executive power. A topical example is the higher education research grant schemes which lack any statutory foundation apart from an appropriation, but which significantly affect the interests of individual researchers. It may be noted in passing that instruments in this category are largely free not only from the parliamentary process, but also, at least until recently, from review by the courts on administrative law grounds. That particular correlation makes regulation through these instruments doubly attractive to government in the circumstances where it represents an effective option.

I have described these categories at some length to establish that the features traditionally associated with the role of parliament as a public forum for rule making are far from universally enjoyed. In the words of a recent paper on the subject, "Parliamentarians, business and the public... are entitled to ask 'What is going on here?'"10 The Administrative Review Council's project is directed to examining the boundary between primary and delegated rule-making: recommending new and rationalised categories for subordinate rules and the procedures by which they should be made; and clarifying the status of some of the more ambiguous instruments. The broader problem is unlikely to be satisfactorily resolved, however, without a reassessment of the role of Parliament in relation to the full range of formal and de facto rules made by a modern state which significantly affect the community or components of it.

\section{FINANCE}

Associated with its legislative function is the role of parliament as the forum in which decisions concerning the twin pillars of government finance, raising the money and spending it, are publicly justified and formally approved. Again for the purposes of argument, the Canadian debate on the Goods and Services Tax notwithstanding, it may be assumed that parliament normally is essentially passive in carrying out this function. The Appropriation bill in particular, as the touchstone for confidence in the government, will be regarded as sacrosanct in every detail by majority members.

Even so, the finance function has similar advantages in terms of accountability and public information to the legislative function. In addition, the role of parliament in relation to public finance has symbolic significance, representing a modem acknowledgement of an historical right of a community to consent, through representatives, to taxation and expenditure decisions. Further, however unlikely it may be to be activated, the power of parliament to refuse to appropriate funds is the sanction which effectively underpins the requirement for government to retain its confidence.

As with the legislative function, however, the framework is incomplete from the standpoint of either accountability or control. In the absence of a dynamic concept of the 
role of parliament in the public financial system, the function has failed to adapt to new forms, new ideas or new needs. Aspects of this debate have been going on for a long time in relation to, for example, the scope and justification for special appropriations which do not require repeated authorization by parliament; financial transactions by government enterprises "off budget": and the occasionally hazardous practice of taxation by press release. There are several other issues also current in Australia that raise the problem in a different guise.

Two which are not particularly new, but have only recently received any degree of prominence, concern conditional transfers between governments and borrowing. The former, which in this context affects only the States, involves the question of whether conditional transfers from the Commonwealth should be credited to the consolidated fund of the State and subject to appropriation by its legislature. The State Constitutions, based on the assumptions of a unitary system of government, provide no clear answer. The practice in fact followed is variable and inconsistent, both between and within States.

The questions concerning borrowing potentially affect both levels of government. They arise from the absence of any clear principle that borrowing, like taxation, requires authorization by parliament, coupled with the analysis of borrowing by government as merely a form of contract which, by definition, can be carried out by the executive branch alone. Strange as it may seem the constitutional rule is still unclear; and while most borrowings can be traced directly or indirectly to statutory authorization there are others which clearly cannot. Whatever the legal logic of the equation with contract may be, the finance function of parliament is patchy indeed if it does not embrace borrowing until, at the earliest, the first instalment of interest falls due.

The final issue is a partial fallout of the privatisation movement. It first came to my attention in the context of a charge of $\$ 240$ for internal review of decisions under the migration legislation. The charge was collected from the date of the budget in which it was announced, but statutory authority was never obtained. The government argued that as the charge was for a service not required to be performed by statute, legislation was unnecessary. It pointed to other charges for not particularly comparable services, which nevertheless showed that there was a genuine issue about where the line was drawn. After 18 months of wrangling involving the ombudsman, the courts, the Attorney-General and the parliament, the government gave way to the point where that fee is no longer imposed. My impression is that the practice is quite widespread however, making resolution of the constitutional question important. Where does the prerogative power to charge for services end, if it exists at all, and the proper role of parliament take over?

Ironically, the inflexibility of the finance function of parliament also constitutes a stumbling block to modernization of government practice. Specific annual appropriations to purpose may not represent the whole of the picture but they represent enough of it to complicate the transition to new financial management procedures. The sense that the institution of parliament is under threat from executive government, moreover, tends to foster resistance to suggestions that the traditional way of doing things might change. 
There would be value in an overhaul of the manner in which financial information is presented to parliament and the procedures followed by it. It must be possible to preserve and enhance the financial accountability of government to parliament, retaining for the latter its ultimate financial sanction without freezing financial management practice forever in the world of Gladstone's nineteenth century England.

\section{MONITORING}

The functions of parliament considered so far are unexceptional in theory and ostensibly achievable in practice, however imperfect their current execution may be. I wish to turn now to a fourth function which, while frequently claimed for parliament, has inherent problems. I refer to the role of parliament in monitoring the activities of government, including both the ministry and the public service.

There are two obstacles in particular to the performance of this function and they are interrelated: one is the party system, and the other is the sheer complexity of government. The former tends to discourage parliament as an institution from indulging in wholehearted monitoring. If the ultimate goal is to uncover enough disarray to dispose of the government, it is understandable that monitoring is a sport with appeal primarily to opposition members. Any contribution of the government members in this regard is likely be made in the privacy of the caucus room. This is important, but is likely to be selective and should not be overstated. In these circumstances, governments are naturally reluctant to provide any more information than is absolutely necessary to parliament. It is hard to convince any of the participants of the value of parliament performing a more effective role through objective scrutiny of executive action, with a view to increasing public knowledge of the affairs of government and keeping both the ministry and the administration on their toes.

Even in the absence of the party system, the complexity of government would make the monitoring role of parliament difficult. As the Chief Justice of the High Court of Australia, Sir Anthony Mason, observed recently in his Blackburn lecture, if the decay of the doctrine of individual ministerial responsibility is justified, as is often claimed, by the complexity of government, "what is beyond the capacity of the Minister is certainly beyond the capacity of Parliament."11 Narrow conceptions of the interests of parliament, the natural reticence of government, and the limited resources of parliament itself merely aggravate the problem.

Because this is the function of parliament which has the highest profile, most jurisdictions have developed a variety of procedures to overcome the manifest difficulties. Experiments with the format of question period are common. Annual departmental reports and some budget reforms increase the information available to parliament. In doing so

11. A. Mason, "Administrative Review - The Experience of the First Twelve Years", The Blackburn Lecture, delivered to the Law Society of the Australian Capital Territory, 7 June 1989. 
they incidentally direct greater attention to the role of the public service, and thus partially counter the inroads on ministerial responsibility. Most important of all has been the development and increasing sophistication of parliamentary committees, including legislation committees, functional standing committees, and estimates committees. Experience suggests that committees help not only to overcome the resource and information problems of parliament but also, to a degree, to defuse party politics.

Nevertheless, it must be accepted that parliament as we know it is never likely to perform this function perfectly, or even adequately. That is not a counsel of despair. I agree that it is important for every effort to be made to ensure that the function is performed as well as possible. Rather it is a counsel of caution, to suggest that we should be realistic about the limitations of parliament in designing the rest of the system. This is an issue in which I have become directly involved from time to time when it is suggested that administrative review package trespasses on the role of parliament in scrutinising executive action. I would argue that the contrary is true: that by bringing executive decision-making into the public domain, and opening up for discussion the rules and the premises on which it is based, administrative review assists parliament to perform its monitoring function in ways which otherwise may not have been possible. This complementary relationship is continuing to develop as the review bodies slowly and cautiously identify circumstances in which their own activities should be wound back because, through parliament, the political process is capable of playing an effective role. ${ }^{12}$ In this respect Australia may have made an uncharacteristically original contribution to the theory and practice of parliamentary government.

\section{E. POLICY}

Let me conclude by briefly mentioning that a possible fifth function for Parliament is the formulation, in contrast to formalisation, of policy. There is of course a threshold question of definition. In practice, the term policy is capable of being used to refer to almost anything a government proposes which has general application, unless it is obviously procedural. There are predictable difficulties in defining a role for a legislature in relation to policy in this sense, in a system in which government depends on the legislature for continuance in office. If any interference with policy is treated as an issue of confidence, the legislature as an institution is precluded from inquiring into the merits of any measures put before it. The contrast with the United States, where policy is regarded as a principal concern of the legislature, is significant. The usual inconsistency between the realities of the parliamentary system and the formal facade again should be noted in passing. Parliaments are quick to object whenever additional difficulties are put in the way of their amendment of bills, however unlikely amendments in fact may have been. In Australia, as in Canada, such objections are most likely to be raised in the 
context of intergovernmental arrangements where, in an unusual display of solidarity, they sometimes attract executive support.

The Australian experience has been that the issue of parliament and policy is more pressing in relation to committees, if only because they are more likely than parliament itself to concern themselves with policy. The terms of reference of the scrutiny committees of the Commonwealth Parliament ostensibly are drawn so as to confine them to non-policy considerations, although the definition of policy is one which might not be recognised in any other context. Other committees, required to consider policy to perform their role at all, rely on government support for their references. While there may be some questioning of the validity and value of the policy distinction, in general it receives bipartisan support. Even if it is to some extent a fiction, it is argued that it helps to prevent polarisation on party lines within committees.

Two points follow, for present purposes. The first is that this self-denying ordinance on the part of parliament points again to limitations on its role which are not consistently acknowledged. The second is that there is room to manoeuvre on this issue if an ethos can be developed which does not require the government and the opposition to treat every change to the substance of a bill as a personal blow or a triumph, respectively. Any movement in this direction is likely to come through the committee system. My impression is that with the committees presently in operation in the parliament in Ottawa, the Canadian system is further developed than the Australian in that regard.

\section{CONCLUSION}

This paper attempts to establish three propositions: that the role of a modern parliament is ambiguous; that parliament does not perform any of the functions usually attributed to it consistently; and that in some cases it is incapable of performing them effectively despite the grandiose claims that are made. These conclusions are not surprising. The parliamentary system has grown like topsy, from the principles and practices of an earlier age. To my knowledge, it has not been subject to comprehensive reappraisal. In particular, nothing has happened to make the theory come to terms with the reality of organised political parties.

While the system muddles along for most of the time not too badly, I would argue that that is not good enough. Parliament is the centrepiece of the constitutional structure. The rest of the system is tailored to suit. If parliament is not working effectively, or if we do not understand what it is doing, there are unavoidable consequences for everything else.

This paper has suggested a variety of changes that might be made. Whatever the merits or otherwise of its individual proposals, the fundamental point is the need to decide what is expected of the legislature in terms of choosing and sustaining government; making law; authorizing public expenditure; monitoring executive action; and, for that matter, doing anything else. The constitutional system should be designed accordingly. Those expectations in turn will reflect recognition and acceptance of the institutional 
advantages and limitations of having particular functions performed by the legislature rather than by other organs of state. If this requires radical rethinking, so be it. 